\title{
Leifsonia rubra sp. nov. and Leifsonia aurea sp. nov., psychrophiles from a pond in Antarctica
}

Correspondence
S. Shivaji
shivas@ccmb.res.in

The genus Leifsonia was created by Evtushenko et al. (2000) to accommodate Gram-positive, non-spore-forming, irregular rod- or filament-shaped, motile, mesophilic and catalase-positive bacteria containing DL-2,4-diaminobutyric acid in the peptidoglycan, MK-11 as the major menaquinone, phosphatidylglycerol and diphosphatidylglycerol as the major phospholipids, a high content of anteiso- and iso-branched fatty acids and a DNA G+C content of 66-73 mol\%. Currently, five species belonging to the genus Leifsonia have been described: Leifsonia poae, isolated from a nematode gall on Poa annua roots (Evtushenko et al., 2000), Leifsonia aquatica, isolated from distilled water (Leifson, 1962), Leifsonia xyli subsp. xyli and L. xyli subsp. cynodontis, respectively isolated from a Saccharum interspecific hybrid and Cynodon dactylon (Davis et al., 1984) and Leifsonia naganoensis and Leifsonia shinshuensis, isolated from soil

Abbreviation: ABM, Antarctic bacterial medium.

The EMBL accession numbers for the 16S rRNA gene sequences of strains CMS $76 r^{\top}$ and CMS $81 y^{\top}$ are AJ438585 and AJ438586.

A UPGMA phenogram including more reference sequences and a table of differences revealed by a comparison of almost-complete 16S rRNA gene sequences of all members of the genus Leifsonia are available as supplementary material in IJSEM Online.
(Suzuki et al., 1999). All five species reported so far are mesophilic. In the present study, we report two psychrophilic strains of Leifsonia isolated from a cyanobacterial mat sample growing luxuriously in a pond in Wright Valley, McMurdo, Antarctica. Both isolates, CMS $76 \mathrm{r}^{\mathrm{T}}$ and CMS $81 \mathrm{y}^{\mathrm{T}}$, were psychrophilic; they could be assigned to the genus Leifsonia on the basis of their phenotypic characteristics, chemotaxonomic features and phylogeny based on $16 \mathrm{~S}$ rRNA gene sequences. Furthermore, strains CMS $76 \mathrm{r}^{\mathrm{T}}$ and CMS $81 y^{\mathrm{T}}$ differed from the five reported species of Leifsonia with respect to many characteristics and are designated as the type strains of the novel species Leifsonia rubra sp. nov. $\left(\right.$ CMS $\left.76 \mathrm{r}^{\mathrm{T}}\right)$ and Leifsonia aurea sp. nov. $\left(\mathrm{CMS} 81 \mathrm{y}^{\mathrm{T}}\right)$.

\section{Source of the organisms, media and growth conditions}

Seven bacterial cultures (CMS 73y, CMS 74y, CMS $76 \mathrm{r}^{\mathrm{T}}$, CMS 77y, CMS 78y, CMS 79y and CMS 81 ${ }^{\mathrm{T}}$ ) were isolated from a cyanobacterial mat sample collected from pond L9 of Wright Valley in McMurdo, Antarctica (Matsumoto, 1993). For this purpose, a fragment of the cyanobacterial mat sample (about $200 \mathrm{mg}$ ) was suspended in $1 \mathrm{ml}$ sterile saline $(150 \mathrm{mM} \mathrm{NaCl})$ and an aliquot $(100 \mu \mathrm{l})$ was plated on 
Antarctic bacterial medium (ABM) containing $0.5 \%(\mathrm{w} / \mathrm{v})$ peptone, $0 \cdot 2 \%(\mathrm{w} / \mathrm{v})$ yeast extract and $1.5 \%(\mathrm{w} / \mathrm{v})$ agar $(\mathrm{pH} 6.9)$ and incubated at $5{ }^{\circ} \mathrm{C}$ (Shivaji et al., 1989). Representative colonies were selected and regrown on $\mathrm{ABM}$ plates to obtain pure cultures of the bacteria. The optimum temperature, $\mathrm{pH}$ and salt concentration for growth of the cultures were determined using ABM plates.

All seven isolates could grow on either $\mathrm{ABM}$ or nutrient agar and colonies were circular, convex, smooth, butyrous and opaque. Furthermore, except for CMS $76 \mathrm{r}^{\mathrm{T}}$ (which was redpigmented), the isolates were yellow-pigmented. These six yellow-pigmented isolates were also identical with respect to their morphology, biochemical and chemotaxonomic characteristics, randomly amplified polymorphic DNA profile and $16 \mathrm{~S}$ rRNA gene sequence, indicating that they are clonal in origin. Therefore, CMS $81 y^{\mathrm{T}}$ was chosen as a representative strain for all six yellow-pigmented isolates.

Randomly amplified polymorphic DNA analysis was carried out as described previously (Shivaji et al., 2000) using the primers OPA-02 (5'-TGCCGAGCT-3') and OPA-03 (5'-AGTGCGCCAC-3').

\section{Morphology, motility and biochemical characteristics}

The morphology of the bacterial cultures during growth and motility were observed by phase-contrast microscopy $(1000 \times)$. All of the biochemical tests described below were performed by growing the cultures at 18 or $22^{\circ} \mathrm{C}$ in the appropriate medium (Hugh \& Leifson, 1953; Stanier et al., 1966; Holding \& Collee, 1971; Stolp \& Gadkari, 1981). For oxidase testing, the method of Kovacs (1956) was used. In this test, stationary-phase cells grown in ABM were used. The ability of the cultures to utilize carbon compounds as sole carbon sources, sensitivity to different antibiotics and the $\mathrm{G}+\mathrm{C}$ content of the DNA were determined as described previously (Shivaji et al., 1991).

Both strains CMS $76 \mathrm{r}^{\mathrm{T}}$ and CMS $81 \mathrm{y}^{\mathrm{T}}$ were found to be Gram-positive, curved, rod-shaped bacteria that are nonmotile, aerobic and positive for catalase. Other details relating to optimal growth conditions, pigment characteristics, utilization of carbon compounds as sole carbon sources, ability to oxidize or ferment sugars, sensitivity to antibiotics and other phenotypic characteristics are included below in the species descriptions (see Tables 1 and 2 for diagnostic characteristics). Pigments were extracted from lyophilized bacterial cell pellets by using methanol and their absorption spectra were recorded in a Hitachi 330 spectrophotometer (Jagannadham et al., 1991).

\section{Phylogenetic analysis}

The 16S rRNA genes of CMS $76 \mathrm{r}^{\mathrm{T}}$ and CMS $81 \mathrm{y}^{\mathrm{T}}$ were amplified and sequenced as published elsewhere (Reddy et al., 2000) and aligned with reference sequences that included all the genera of the family using the multiple sequence alignment program CLUSTAL V (Higgins et al., 1992). The program DNADIST, with the Kimura-2 parameter, was used to compute pairwise evolutionary distances for the above aligned sequences (Kimura, 1980). The original sequence dataset was resampled 1000 times using SEQBOOT and subjected to bootstrap analysis. Phylogenetic trees were constructed using parsimony analysis (DNAPARS) and using various distance matrix-based clustering algorithms such as FITCH, KITCH and UPGMA (Felsenstein, 1993). Majorityrule $(50 \%)$ consensus trees were also constructed using CONSENSE (Felsenstein, 1993). In all cases, input order of species added to the topology of the tree was randomized with the jumble option of 7 and 10 replications.

The different algorithms gave consistent results. On the basis of the 16S rRNA gene sequence, it was clear that strains CMS $76 \mathrm{r}^{\mathrm{T}}$ and CMS $81 \mathrm{y}^{\mathrm{T}}$ are closely related to one another (97.5\% similarity) and to the reported species of Leifsonia (95-96\%) with an evolutionary distance of $2.5 \%$ between themselves and $4-5 \%$ from the reported species, as calculated by the Kimura-2 parameter of the DNADIST program. In fact, the phylogenetic tree clearly demonstrated that CMS $76 \mathrm{r}^{\mathrm{T}}$ and CMS $81 \mathrm{y}^{\mathrm{T}}$ are closely related; they formed a robust and separate clade with a bootstrap value of $100 \%$ and clustered with the other five species of Leifsonia (Fig. 1) with a bootstrap value of $62 \%$. Furthermore, the topology of the tree was similar to the one reported previously (Evtushenko et al., 2000).

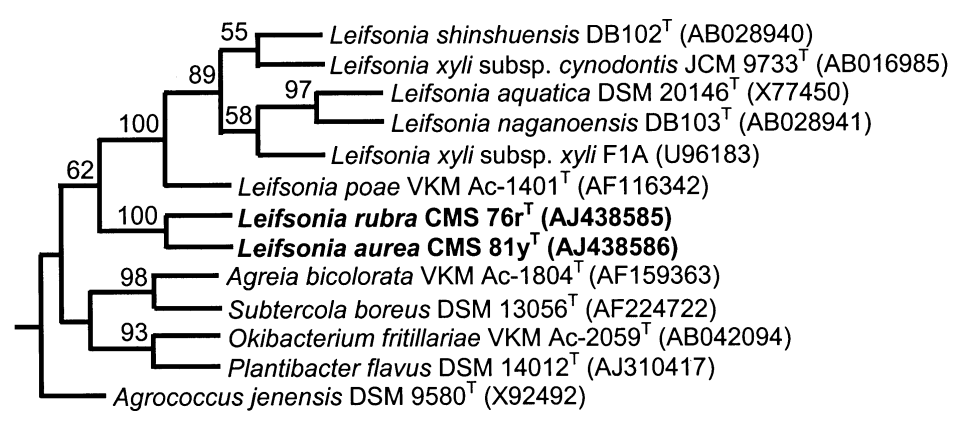

Fig. 1. UPGMA phenogram showing the phylogenetic relationships between $L$. rubra sp. nov. CMS $76 \mathrm{r}^{\top}$ and $L$. aurea sp. nov. CMS $81 y^{\top}$ and other species of the genus Leifsonia and related reference microorganisms based on 16S rRNA gene sequence analysis. Bootstrap values are given at the nodes. Branch lengths are not to scale. A version of the phenogram including a wider selection of reference taxa is available as supplementary material in IJSEM Online. 
However, although strains CMS $76 \mathrm{r}^{\mathrm{T}}$ and CMS $81 \mathrm{y}^{\mathrm{T}}$ show $97 \cdot 5 \%$ relatedness at the $16 \mathrm{~S}$ rRNA gene level, they probably represent two distinct species, since the overall genome relatedness between the two, based on DNA-DNA hybridization performed using the membrane filter method of Tourova \& Antonov (1987) as described previously (Reddy et al., 2002a), was only $30 \%$.

\section{Chemotaxonomic studies}

The methods used for the identification of fatty acids (Sato \& Murata, 1988), quinones (Collins et al., 1977; Dunphy et al., 1971), polar lipids (Komagata \& Suzuki, 1987), peptidoglycan (Rosenthal \& Dziarski, 1994; Schleifer \& Kandler, 1972) and cell-wall sugars (Komagata \& Suzuki, 1987) and determination of the DNA G + C content were described previously (Reddy et al., 2002b). For fatty acid analysis, strains CMS $76 \mathrm{r}^{\mathrm{T}}$, CMS $81 \mathrm{y}^{\mathrm{T}}$ and L. aquatica ATCC $14665^{\mathrm{T}}$ were cultured in CB liquid medium (Zgurskaya et al., 1993) at $25^{\circ} \mathrm{C}$.

The phylogenetic affiliation of strains CMS $76 \mathrm{r}^{\mathrm{T}}$ and CMS $81 \mathrm{y}^{\mathrm{T}}$ to the genus Leifsonia is supported further by their chemotaxonomic properties, such as the presence of glycine, glutamic acid, 2,4-diaminobutyric acid and alanine in the cell-wall peptidoglycan, MK-11 as the major menaquinone, phosphatidylglycerol and diphosphatidylglycerol as the principal phospholipids and anteiso- $\mathrm{C}_{15: 0}$, anteiso- $\mathrm{C}_{17: 0}$ and iso- $\mathrm{C}_{16: 0}$ as the predominant fatty acids and the DNA $\mathrm{G}+\mathrm{C}$ content of $64-66 \mathrm{~mol} \%$.

\section{Conclusions}

Strains CMS $76 \mathrm{r}^{\mathrm{T}}$ and CMS $81 \mathrm{y}^{\mathrm{T}}$ conform to the description of the genus Leifsonia in that they are Gram-positive, curved rods, non-motile and catalase-positive, contain 2,4diaminobutyric acid in the peptidoglycan, contain menaquinone MK-11, phosphatidylglycerol and diphosphatidylglycerol, have a high content of anteiso- and isobranched fatty acids and have a DNA G $+\mathrm{C}$ content of $64-66 \mathrm{~mol} \%$. In addition, CMS $76 \mathrm{r}^{\mathrm{T}}$ is closely related to CMS $81 y^{T}$ with respect to many phenotypic and chemotaxonomic characteristics (Tables 1 and 2). However, it differed from CMS $81 y^{\mathrm{T}}$ in that it was red-pigmented, did not grow at temperatures above $22^{\circ} \mathrm{C}$, gave a negative Voges-Proskauer test, did not utilize arginine or erythritol as sole carbon sources and contained rhamnose as an additional cell-wall sugar (Table 1). Furthermore, CMS $76 \mathrm{r}^{\mathrm{T}}$ had higher proportions of $\mathrm{C}_{15: 0}(3 \cdot 6 \%)$, iso- $\mathrm{C}_{15: 0}$ $(7 \cdot 8 \%)$ and iso- $\mathrm{C}_{16: 0}(11 \cdot 5 \%)$ and lower levels of anteiso$\mathrm{C}_{17: 0}(20 \cdot 3 \%)$ and iso- $\mathrm{C}_{17: 0}(1 \cdot 8 \%)$ (Table 2). In addition, there was a difference of $2.5 \%$ at the $16 \mathrm{~S}$ rDNA sequence level between the two isolates and they were related by only $30 \%$ at the whole-genome level, as evidenced by DNADNA relatedness studies. These characteristics clearly establish that CMS $76 \mathrm{r}^{\mathrm{T}}$ and CMS $81 \mathrm{y}^{\mathrm{T}}$ represent two separate species.

Strain CMS $76 \mathrm{r}^{\mathrm{T}}$ is different from all the other reported species of the genus Leifsonia (including CMS $81 y^{\mathrm{T}}$ ) in that it is red-pigmented and psychrophilic (with a growth temperature of $0-22{ }^{\circ} \mathrm{C}$ ). Furthermore, it had higher proportions of $\mathrm{C}_{15: 0}$ and iso- $\mathrm{C}_{15: 0}$ compared with CMS $81 \mathrm{y}^{\mathrm{T}}$, $L$. aquatica and $L$. poae, which were analysed following growth in CB liquid medium at $25^{\circ} \mathrm{C}$. Data for L. aquatica ATCC $14665^{\mathrm{T}}$ were acquired in the present study, whereas data for L. poae were from Evtushenko et al. (2000). The fatty acids $\mathrm{C}_{14: 0}, \mathrm{C}_{15: 0}, \mathrm{C}_{18: 0}, \mathrm{C}_{15: 1}$ and $\mathrm{C}_{18: 1}$ were absent from L. xyli subsp. cynodontis, $L$. naganoensis and L. shinshuensis (Suzuki et al., 1999). In addition, CMS $76 \mathrm{r}^{\mathrm{T}}$ showed a number of distinct differences from the reported species of Leifsonia, as listed in Table 1. Furthermore, at the 16S rRNA gene sequence level, CMS $76 \mathrm{r}^{\mathrm{T}}$ differed from L. aquatica, L. poae, L. xyli subsp. xyli, $L$. xyli subsp. cynodontis, L. naganoensis and L. shinshuensis by $4 \cdot 2,3 \cdot 8,4 \cdot 6,4 \cdot 5,4 \cdot 1$ and $4 \cdot 9 \%$, respectively. Thus, on the basis of differences in phenotypic traits (Table 1), distinct fatty acid types (Table 2 ) and the $>3 \%$ difference at the $16 \mathrm{~S}$ rRNA gene sequence level (except for CMS $81 y^{\mathrm{T}}$, for which the value was $\sim 2.5 \%$ ), CMS $76 \mathrm{r}^{\mathrm{T}}$ has been assigned the status of a novel species, for which the name L. rubra sp. nov. is proposed. It is worthwhile to mention that strains with more than a $3 \%$ difference at the $16 \mathrm{~S} \mathrm{rDNA}$ level are unlikely to have a DNA-DNA relatedness of more than $70 \%$ (Stackebrandt \& Goebel, 1994).

Strain CMS $81 y^{\mathrm{T}}$ can also be differentiated from CMS $76 \mathrm{r}^{\mathrm{T}}$ and $L$. aquatica, $L$. poae, $L$. xyli subsp. xyli, L. xyli subsp. cynodontis, L. naganoensis and L. shinshuensis on the basis of phenotypic traits and chemotaxonomic properties (Tables 1 and 2). In addition, its $16 \mathrm{~S}$ rRNA gene sequence differs from those of L. poae, L. aquatica, L. xyli subsp. xyli, L. xyli subsp. cynodontis, $L$. naganoensis and $L$. shinshuensis by $3 \cdot 9,4 \cdot 3,4 \cdot 6,4 \cdot 2,4 \cdot 9$ and $4 \cdot 8 \%$ (but by only $2 \cdot 5 \%$ from that of CMS $76 \mathrm{r}^{\mathrm{T}}$ ). Therefore, CMS $81 \mathrm{y}^{\mathrm{T}}$ has also been assigned the status of a novel species, for which the name L. aurea sp. nov. is proposed.

Despite the fact that strains CMS $76 \mathrm{r}^{\mathrm{T}}$ and CMS $81 \mathrm{y}^{\mathrm{T}}$ formed a coherent cluster with the clade of Leifsonia species, a high level of dissimilarity was observed at the 16S rDNA sequence level. The reason for this is that, when $1407 \mathrm{bp}$ (positions 110-1517 according to Escherichia coli numbering) of the 16S rRNA gene sequences of all species of the genus Leifsonia were compared, a total of 115 nucleotide changes were observed, spanning the entire region (details available as supplementary material in IJSEM Online). Contributing to this change is an insertion of $14 \mathrm{bp}$ from positions 461 to 474 observed only in CMS $76 \mathrm{r}^{\mathrm{T}}$ and CMS $81 \mathrm{y}^{\mathrm{T}}$. In addition, two variable regions were observed, spanning positions 148 to 226 (around 31 variable positions) and positions 613 to 631 (7 variable positions). The significance of these insertions or variable regions is not clear, but the occurrence of the insertion in only the psychrophilic species may prove useful as a signature for these isolates; this awaits clarification in future studies. 
Table 1. Characteristics that differentiate strains CMS $76 \mathrm{r}^{\top}$ and $C M S 81 \mathrm{y}^{\top}$ from each other and from reported species of Leifsonia

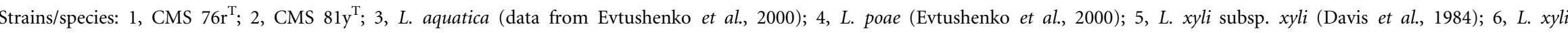

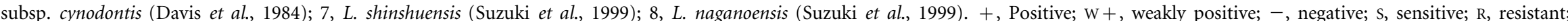
NA, not available; ND, not determined.

\begin{tabular}{|c|c|c|c|c|c|c|c|c|}
\hline Characteristic & 1 & 2 & 3 & 4 & 5 & 6 & 7 & 8 \\
\hline Colony colour & Red & Yellow & Yellow & Yellow & White & Yellow & White & White \\
\hline Motility & - & - & + & + & - & - & - & - \\
\hline Growth temperature $\left({ }^{\circ} \mathrm{C}\right)$ & $0-22$ & $0-30$ & $7-37$ & $7-37$ & $7-31$ & $7-35$ & $7-42$ & $7-37$ \\
\hline Oxidase, $\mathrm{H}_{2} \mathrm{~S}$ production & - & - & + & - & - & - & $\mathrm{NA}$ & $\mathrm{NA}$ \\
\hline Gelatinase, aesculin hydrolysis & - & - & - & + & - & - & NA & NA \\
\hline Starch hydrolysis & - & - & + & - & - & + & + & + \\
\hline Methyl red test & - & - & - & + & - & + & NA & NA \\
\hline Voges-Proskauer test & - & + & - & + & - & + & NA & $\mathrm{NA}$ \\
\hline Major menaquinone(s) & MK-11 & MK-11 & MK-11, MK-10 & MK-11 & $\mathrm{ND}$ & MK-11, MK-12 & MK-11, MK-12 & MK-11, MK-10 \\
\hline Cell-wall sugars ${ }^{*}$ & $\begin{array}{l}\text { Gal, Glc, } \\
\text { Rib, Rha }\end{array}$ & $\begin{array}{l}\text { Gal, Glc, } \\
\text { Rib }\end{array}$ & $\begin{array}{c}\text { Gal, Glc, Rib, } \\
\text { Rha, Fuc }\end{array}$ & $\begin{array}{l}\text { Gal, Glc, } \\
\text { Rib, Rha }\end{array}$ & $\begin{array}{l}\text { Gal, Rha, } \\
\text { Fuc }\end{array}$ & $\begin{array}{l}\text { Gal, Rha, } \\
\text { Fuc }\end{array}$ & $\mathrm{ND}$ & ND \\
\hline \multicolumn{9}{|l|}{ Production of acid from: } \\
\hline L-Arabinose & - & - & - & + & - & - & ND & ND \\
\hline D-Fructose & - & - & + & + & - & - & + & + \\
\hline D-Galactose, sucrose & - & - & + & + & - & - & - & + \\
\hline D-Glucose & - & - & + & - & + & + & - & + \\
\hline D-Maltose & - & - & - & - & + & + & - & + \\
\hline D-Mannose & - & - & + & + & - & + & - & + \\
\hline $\mathrm{G}+\mathrm{C}$ content of DNA $(\mathrm{mol} \%)$ & 66 & 64 & 70 & NA & 66 & 69 & 71 & 71 \\
\hline \multicolumn{9}{|l|}{ Utilization of carbon compounds: } \\
\hline L-Alanine & - & - & - & - & NA & - & + & $\mathrm{w}+$ \\
\hline L-Arabinose & - & - & - & + & NA & - & NA & NA \\
\hline Adonitol & - & - & + & - & NA & NA & NA & NA \\
\hline D-Cellobiose, lactose & - & - & + & + & NA & - & - & + \\
\hline Dextran & - & - & + & + & NA & NA & $\mathrm{w}+$ & + \\
\hline Dulcitol & - & - & + & + & NA & - & NA & NA \\
\hline meso-Erythritol & - & + & - & - & NA & NA & NA & NA \\
\hline D-Fructose & + & + & + & + & NA & $\mathrm{w}+$ & + & + \\
\hline D-Galactose & + & + & + & + & NA & - & $\mathrm{w}+$ & + \\
\hline D-Glucose & + & + & + & + & NA & $\mathrm{w}+$ & - & + \\
\hline meso-Inositol & - & - & + & - & NA & - & + & + \\
\hline D-Maltose & - & - & + & + & NA & - & $\mathrm{w}+$ & + \\
\hline D-Mannitol & - & - & + & + & NA & $\mathrm{w}+$ & + & + \\
\hline D-Mannose & + & + & + & + & NA & $\mathrm{w}+$ & $\mathrm{w}+$ & + \\
\hline D-Melibiose & - & - & + & + & $\mathrm{NA}$ & - & $\mathrm{w}+$ & $\mathrm{w}+$ \\
\hline
\end{tabular}


Table 1. cont.

\begin{tabular}{|c|c|c|c|c|c|c|c|c|}
\hline Characteristic & 1 & 2 & 3 & 4 & 5 & 6 & 7 & 8 \\
\hline Melezitol & - & - & + & - & $\mathrm{NA}$ & - & $\mathrm{w}+$ & $\mathrm{w}+$ \\
\hline Pyruvate & + & + & + & $\mathrm{W}+$ & NA & $\mathrm{w}+$ & $\mathrm{w}+$ & $\mathrm{w}+$ \\
\hline D-Raffinose & - & - & - & + & NA & $\mathrm{NA}$ & $\mathrm{NA}$ & $\mathrm{NA}$ \\
\hline D-Rhamnose & - & - & $\mathrm{W}+$ & - & NA & - & $\mathrm{w}+$ & - \\
\hline D-Ribose & + & + & - & - & NA & - & $\mathrm{w}+$ & $\mathrm{w}+$ \\
\hline Sodium citrate & - & - & NA & $\mathrm{ND}$ & - & NA & $\mathrm{NA}$ & $\mathrm{NA}$ \\
\hline Sodium acetate & + & + & NA & $\mathrm{ND}$ & - & - & NA & NA \\
\hline Sodium succinate & - & - & NA & $\mathrm{ND}$ & NA & - & NA & NA \\
\hline D-Sorbitol & - & - & $\mathrm{w}+$ & - & NA & - & $\mathrm{w}+$ & $\mathrm{w}+$ \\
\hline D-Sorbose & + & + & + & - & NA & NA & $\mathrm{NA}$ & $\mathrm{NA}$ \\
\hline Sucrose & - & - & + & + & NA & - & + & + \\
\hline Trehalose & + & + & + & - & NA & - & $\mathrm{w}+$ & $\mathrm{w}+$ \\
\hline D-Xylose & - & - & + & + & NA & - & $\mathrm{w}+$ & $\mathrm{w}+$ \\
\hline L-Arginine & - & + & NA & NA & NA & - & $\mathrm{w}+$ & $\mathrm{w}+$ \\
\hline \multicolumn{9}{|l|}{ Sensitivity to antibiotics: } \\
\hline Penicillin & $\mathrm{R}$ & s & $\mathrm{R}$ & $\mathrm{R}$ & NA & NA & NA & NA \\
\hline Streptomycin, ampicillin, tetracycline & s & s & $\mathrm{R}$ & $\mathrm{R}$ & NA & $\mathrm{NA}$ & NA & NA \\
\hline Erythromycin & s & $\mathrm{R}$ & NA & NA & NA & $\mathrm{NA}$ & NA & NA \\
\hline Lincomycin & S & $\mathrm{R}$ & $\mathrm{R}$ & $\mathrm{R}$ & NA & $\mathrm{NA}$ & NA & NA \\
\hline Rifampicin & S & S & S & $\mathrm{R}$ & NA & NA & NA & NA \\
\hline
\end{tabular}

${ }^{\star}$ Fuc, Fucose; Gal, galactose; Glc, glucose; Rha, rhamnose; Rib, ribose. 
Table 2. Fatty acid composition of strains CMS $76 \mathrm{r}^{\top}$ and $\mathrm{CMS} 81 \mathrm{y}^{\top}$ and related species

Strains/species: 1, CMS $76 \mathrm{r}^{\mathrm{T}}$; 2, CMS $81 \mathrm{r}^{\mathrm{T}} ; 3$, L. aquatica ATCC $14665^{\mathrm{T}}$; 4, L. poae (data from Evtushenko et al., 2000); 5, L. xyli subsp. cynodontis (Suzuki et al., 1999); 6, L. naganoensis (Suzuki et al., 1999); 7, L. shinshuensis (Suzuki et al., 1999). CMS 76r ${ }^{\mathrm{T}}$, CMS 81y ${ }^{\mathrm{T}}$ and L. aquatica ATCC $14665^{\mathrm{T}}$ were grown in CB liquid medium at $25^{\circ} \mathrm{C}$ and analysed for fatty acid methyl esters in the present study. Absent.

\begin{tabular}{|c|c|c|c|c|c|c|c|}
\hline Fatty acid & 1 & 2 & 3 & 4 & 5 & 6 & 7 \\
\hline \multicolumn{8}{|c|}{ Saturated fatty acids } \\
\hline $\mathrm{C}_{14: 0}$ & $1 \cdot 3$ & $0 \cdot 2$ & $0 \cdot 3$ & - & - & - & - \\
\hline $\mathrm{C}_{16: 0}$ & $1 \cdot 8$ & $1 \cdot 4$ & $0 \cdot 5$ & $<1 \cdot 0$ & $1 \cdot 6$ & $3 \cdot 7$ & $<0.5$ \\
\hline $\mathrm{C}_{18: 0}$ & $3 \cdot 7$ & $4 \cdot 3$ & - & $<1 \cdot 0$ & - & - & - \\
\hline $\mathrm{C}_{18: 1}$ & $5 \cdot 0$ & $4 \cdot 1$ & - & $<1 \cdot 0$ & - & - & - \\
\hline \multicolumn{8}{|c|}{ Branched-chain fatty acids } \\
\hline iso- $\mathrm{C}_{14: 0}$ & $0 \cdot 5$ & $0 \cdot 2$ & $0 \cdot 02$ & - & $<0.5$ & $<0 \cdot 5$ & $<0.5$ \\
\hline iso- $\mathrm{C}_{15: 0}$ & $7 \cdot 8$ & $3 \cdot 3$ & $0 \cdot 8$ & $1 \cdot 0$ & $0 \cdot 5$ & $1 \cdot 3$ & $0 \cdot 7$ \\
\hline anteiso- $\mathrm{C}_{15: 0}$ & $37 \cdot 5$ & $43 \cdot 7$ & $29 \cdot 8$ & $36 \cdot 3$ & $34 \cdot 1$ & $42 \cdot 1$ & $47 \cdot 3$ \\
\hline
\end{tabular}

\section{Description of Leifsonia rubra sp. nov.}

Leifsonia rubra (rub'ra. L. fem. adj. rubra reddish, referring to the reddish pigment that the bacterium produces).

Colonies are circular, convex, smooth, butyrous, opaque, red-pigmented and 1-2 $\mathrm{mm}$ in diameter. Cells are aerobic, Gram-positive, non-motile, curved rods. The pigment is insoluble in water but soluble in methanol and exhibits characteristic peaks at 420,443, 490 and $520 \mathrm{~nm}$ in methanol. Grows between 0 and $22^{\circ} \mathrm{C}$ and between $\mathrm{pH} 6$ and 12 and tolerates up to $3 \% \mathrm{NaCl}$. Optimum growth is observed at $15^{\circ} \mathrm{C}, \mathrm{pH} 7$ and in the absence of $\mathrm{NaCl}$. Positive for catalase and $\beta$-galactosidase and reduces nitrate to nitrite. Negative for oxidase, urease, lipase, gelatinase, phosphatase and indole, gives negative results in methyl red and Voges-Proskauer tests, is negative for $\mathrm{H}_{2} \mathrm{~S}$ production and does not hydrolyse aesculin or starch. Does not produce acid from L-arabinose, D-fructose, D-galactose, glucosamine, lactose, D-maltose, D-mannose, L-rhamnose, sucrose or D-xylose. Utilizes D-fructose, D-glucose, Dgalactose, glucosamine, glycerol, D-mannose, pyruvate, Lrhamnose, D-ribose, sodium acetate, D-sorbose, trehalose, L-glutamic acid and L-phenylalanine as sole carbon sources, and fails to utilize L-arabinose, adonitol, ammonium acetate, D-cellobiose, cellulose, creatinine, dextran, dulcitol, meso-erythritol, glycogen, $\beta$-hydroxybutyric acid, inositol, inulin, lactose, lactic acid, D-maltose, D-mannitol, Dmelibiose, melezitol, myristic acid, polyethylene glycol, potassium hydrogen phthalate, D-raffinose, sodium citrate, sodium succinate, sorbitol, sucrose, D-xylose, L-alanine, L-arginine, L-glycine, L-glutamine, L-lysine, L-methionine, L-serine, L-tyrosine and L-tryptophan. Sensitive to novobiocin, cefaperazone, cefazoline, kanamycin, amoxycillin, tobramycin, roxithromycin, vancomycin, cephatoxime, streptomycin, erythromycin, amikacin, ampicillin, lincomycin, tetracycline and rifampicin and resistant to penicillin, colistin, cefuroxime, nitrofurantoin, ciprofloxacin, cotrimoxazole, norfloxacin and chloramphenicol. The peptidoglycan contains DL-diaminobutyric acid as the diamino acid, along with glycine, glutamic acid and alanine. The cell-wall sugars are galactose, glucose, ribose and rhamnose. The major menaquinone is MK-11. Fatty acid methyl esters are listed in Table 2 . The $\mathrm{G}+\mathrm{C}$ content of the DNA of the type strain is $66 \mathrm{~mol} \%$.

The type strain is strain CMS $76 \mathrm{r}^{\mathrm{T}}\left(=\mathrm{MTCC} 4210^{\mathrm{T}}=\right.$ DSM $15304^{\mathrm{T}}=$ CIP $107783^{\mathrm{T}}$ ).

\section{Description of Leifsonia aurea sp. nov.}

Leifsonia aurea (au're.a. L. fem. adj. aurea golden, referring to the yellowish pigment that the bacterium produces).

Colonies are yellowish, circular, convex, smooth, butyrous, opaque, yellow-pigmented and 1-2 $\mathrm{mm}$ in diameter. Cells are aerobic, Gram-positive, curved, non-motile rods. The pigment is insoluble in water but soluble in methanol and exhibits four characteristic peaks, at 390, 414, 438 and $468 \mathrm{~nm}$. Grows between 0 and $30^{\circ} \mathrm{C}$ and between $\mathrm{pH} 6$ and 11 and tolerates up to $3 \% \mathrm{NaCl}$. Optimum growth occurs at $22^{\circ} \mathrm{C}, \mathrm{pH} 7$ and in the absence of salt. Positive for catalase and $\beta$-galactosidase, gives a positive result in the Voges-Proskauer test and reduces nitrate to nitrite. Negative for oxidase, urease, lipase, gelatinase, phosphatase and indole, gives a negative result in the methyl red test, is negative for $\mathrm{H}_{2} \mathrm{~S}$ production and does not hydrolyse aesculin or starch. Does not produce acid from L-arabinose, 
D-fructose, D-galactose, D-glucose, lactose, D-maltose, D-mannose, L-rhamnose, sucrose or D-xylose. Does not grow on minimal medium containing L-arabinose, adonitol, ammonium acetate, D-cellobiose, cellulose, creatinine, dextran, dulcitol, glycogen, $\beta$-hydroxybutyric acid, inositol, inulin, lactose, lactic acid, D-maltose, D-mannitol, Dmelibiose, melezitol, myristic acid, polyethylene glycol, potassium hydrogen phthalate, D-raffinose, sodium citrate, sodium succinate, sorbitol, sucrose, D-xylose, L-alanine, L-glycine, L-glutamine, L-lysine, L-methionine, L-serine, L-tyrosine or L-tryptophan. Can grow on erythritol, D-fructose, D-glucose, D-galactose, glucosamine, glycerol, D-mannose, pyruvate, L-rhamnose, D-ribose, sodium acetate, D-sorbose, trehalose, L-arginine, L-glutamic acid and L-phenylalanine as sole carbon sources. Resistant to colistin, nitrofurantoin, cotrimoxazole, erythromycin, norfloxacin, lincomycin and chloramphenicol and sensitive to novobiocin, cefaperazone, cefazoline, penicillin, kanamycin, cefuroxime, amoxycillin, ciprofloxacin. tobramycin, roxithromycin, vancomycin, cephatoxime, streptomycin, amikacin, ampicillin, tetracycline and rifampicin. The peptidoglycan contains DL-diaminobutyric acid as the diamino acid, along with glycine, glutamic acid and alanine, and the cell-wall sugars are galactose, glucose and ribose. The major menaquinone is MK-11. Fatty acid methyl esters are listed in Table 2. The $\mathrm{G}+\mathrm{C}$ content of the DNA of the type strain is $64 \mathrm{~mol} \%$.

The type strain is strain CMS $81 y^{\mathrm{T}}\left(=\right.$ MTCC $4657^{\mathrm{T}}=$ DSM $15303^{\mathrm{T}}=$ CIP $107785^{\mathrm{T}}$ ).

\section{Acknowledgements}

This work was supported by a grant from the Department of Biotechnology, Government of India and the Indo-French Centre for Promotion of Advanced Research, New Delhi, India.

\section{References}

Collins, M. D., Pirouz, T., Goodfellow, M. \& Minnikin, D. E. (1977). Distribution of menaquinones in actinomycetes and corynebacteria. J Gen Microbiol 100, 221-230.

Davis, M. J., Gillaspie, A. G., Jr, Vidaver, A. K. \& Harris, R. W. (1984). Clavibacter: a new genus containing some phytopathogenic coryneform bacteria, including Clavibacter xyli subsp. xyli sp. nov., subsp. nov. and Clavibacter xyli subsp cynodontis subsp. nov., pathogens that cause ratoon stunting disease of sugarcane and burmudagrass stunting disease. Int J Syst Bacteriol 34, 107-117.

Dunphy, P. J., Phillips, P. G. \& Brodie, A. F. (1971). Separation and identification of menaquinones from microorganisms. J Lipid Res 12, 442-449.

Evtushenko, L. I., Dorofeeva, L. V., Subbotin, S. A., Cole, J. R. \& Tiedje, J. M. (2000). Leifsonia poae gen. nov., sp. nov., isolated from nematode galls on Poa annua, and reclassification of 'Corynebacterium aquaticum' Leifson 1962 as Leifsonia aquatica (ex Leifson 1962) gen. nov., nom. rev., comb. nov. and Clavibacter xyli Davis et al. 1984 with two subspecies as Leifsonia xyli (Davis et al. 1984) gen. nov., comb. nov. Int J Syst Evol Microbiol 50, 371-380.
Felsenstein, J. (1993). PHYLIP (phylogeny inference package) version $3.5 \mathrm{c}$. Distributed by the author. Department of Genetics, University of Washington, Seattle, USA.

Higgins, D. G., Bleasby, A. J. \& Fuchs, R. (1992). Clustal V: improved software for multiple sequence alignment. Comput Appl Biosci 8, 189-191.

Holding, A. J. \& Collee, J. G. (1971). Routine biochemical tests. Methods Microbiol 6A, 2-32.

Hugh, R. \& Leifson, E. (1953). The taxonomic significance of fermentative versus oxidative metabolism of carbohydrates by various gram-negative bacteria. J Bacteriol 66, 24-26.

Jagannadham, M. V., Jayathirtha Rao, V. \& Shivaji, S. (1991). The major carotenoid pigment of a psychrotrophic Micrococcus roseus strain: purification, structure, and interaction with synthetic membranes. J Bacteriol 173, 7911-7917.

Kimura, M. (1980). A simple method for estimating evolutionary rates of base substitutions through comparative studies of nucleotide sequences. J Mol Evol 16, 111-120.

Komagata, K. \& Suzuki, K. I. (1987). Lipid and cell wall analysis in bacterial systematics. Methods Microbiol 19, 161-206.

Kovacs, N. (1956). Identification of Pseudomonas pyocyanea by the oxidase reaction. Nature 178, 703.

Leifson, E. (1962). The bacterial flora of distilled and stored water. III. New species of the genera Corynebacterium, Flavobacterium, Spirillum and Pseudomonas. Int Bull Bacteriol Nomencl Taxon 12, 161-170.

Matsumoto, G. I. (1993). Geochemical features of the McMurdo Dry Valley lakes, Antarctica. Physical and biogeochemical processes in Antarctic Lakes. Antarct Res Ser 49, 95-118.

Reddy, G. S. N., Aggarwal, R. K., Matsumoto, G. I. \& Shivaji, S. (2000). Arthrobacter flavus sp. nov., a psychrophilic bacterium isolated from a pond in McMurdo Dry Valley, Antarctica. Int J Syst Evol Microbiol 50, 1553-1561.

Reddy, G. S. N., Prakash, J. S. S., Matsumoto, G. I., Stackebrandt, E. \& Shivaji, S. (2002a). Arthrobacter roseus sp. nov., a psychrophilic bacterium isolated from an Antarctic cyanobacterial mat sample. Int J Syst Evol Microbiol 52, 1017-1021.

Reddy, G. S. N., Prakash, J. S. S., Vairamani, M., Prabhakar, S., Matsumoto, G. I. \& Shivaji, S. (2002b). Planococcus antarcticus and Planococcus psychrophilus spp. nov. isolated from cyanobacterial mat samples collected from ponds in Antarctica. Extremophiles 6, 253-261.

Rosenthal, R. S. \& Dziarski, R. (1994). Isolation of peptidoglycan and soluble peptidoglycan fragments. Methods Enzymol 235, 253-285.

Sato, N. S. \& Murata, N. (1988). Membrane lipids. Methods Enzymol 167, 251-259.

Schleifer, K. H. \& Kandler, O. (1972). Peptidoglycan types of bacterial cell walls and their taxonomic implications. Bacteriol Rev 36, 407-477.

Shivaji, S., Rao, N. S., Saisree, L., Reddy, G. S. N., Seshu Kumar, G. \& Bhargava, P. M. (1989). Isolates of Arthrobacter from the soils of Schirmacher Oasis, Antarctica. Polar Biol 10, 225-229.

Shivaji, S., Ray, M. K., Seshu Kumar, G., Reddy, G. S. N., Saisree, L. \& Wynn Williams, D. D. (1991). Identification of Janthinobacterium lividum from the soils of the islands of Scotia Ridge and from Antarctic peninsula. Polar Biol 11, 267-272.

Shivaji, S., Vijaya Bhanu, N. \& Aggarwal, R. K. (2000). Identification of Yersinia pestis as the causative organism of plague in India as determined by $16 \mathrm{~S}$ rDNA sequencing and RAPD-based genomic fingerprinting. FEMS Microbiol Lett 189, 247-252. 
Stackebrandt, E. \& Goebel, B. M. (1994). Taxonomic note: a place for DNA-DNA reassociation and 16S rRNA sequence analysis in the present species definition in bacteriology. Int J Syst Bacteriol 44, 846-849.

Stanier, R. Y., Palleroni, N. J. \& Doudoroff, M. (1966). The aerobic pseudomonads: a taxonomic study. J Gen Microbiol 43, 159-271.

Stolp, H. \& Gadkari, D. (1981). Nonpathogenic members of the genus Pseudomonas. In The Prokaryotes, vol. 1, pp. 719-741. Edited by M. P. Starr, H. G. Trüper, A. Balows \& H. G. Schlegel. Berlin: Springer.

Suzuki, K., Suzuki, M., Sasaki, J., Park, Y. H. \& Komagata, K. (1999). Leifsonia gen. nov., a genus for 2,4-diaminobutyric acid-containing actinomycetes to accommodate "Corynebacterium aquaticum" Leifson 1962 and Clavibacter xyli subsp. cynodontis Davis et al. 1984. J Gen Appl Microbiol 45, 253-262.

Tourova, T. P. \& Antonov, A. S. (1987). Identification of microorganisms by rapid DNA-DNA hybridization. Methods Microbiol 19, 333-355.

Zgurskaya, H. I., Evtushenko, L. I., Akimov, V. N. \& Kalakoutskii, L. V. (1993). Rathayibacter gen. nov., including the species Rathayibacter rathayi comb. nov., Rathayibacter tritici comb. nov., Rathayibacter iranicus comb. nov., and six strains from annual grasses. Int J Syst Bacteriol 43, 143-149. 